J. Perinat. Med. 13 (1985) 277

\section{Positron emission tomography in experimental perinatology}

\author{
B. S. Lindberg, L. Berglund, P. Hartvig*, P. G. Lindgren**, A. Lilja**, H. \\ Lundqvist****, B. Långström*****, A. Rane***
}

Department of Obstetrics and Gynecology, *Hospital Pharmacy, **Department of Diagnostic Radiology, ${ }^{* * *}$ Department of Clinical Pharmacology, Uppsala University, Akademiska Sjukhuset, Uppsala, ****Gustaf Werners Institute, $* * * * *$ Department of Organic Chemistry, Institute of Chemistry, University of Uppsala, Sweden

\section{Introduction}

The mother, placenta and the fetus are functionally and anatomically integrated but the interplay between the parts of this fetomaternal unit is difficult to study. In prenatal pharmacology, toxicology, reproductive endocrinology and in nutritional research the events in and the interplay between the tissues are of particular interest to study. A noninvasive technique which gives sequential information on the transfer of substances across the placenta is therefore a great value.

Positron emission tomography (PET) is a new technique which has been introduced during the last few years for in vito studies of pharmacological, physiological and biochemical processes in the living body. We have employed and introduced the PET technique in experimental perinatal medicine.

Our studies so far have been performed in the feto-maternal unit of Rhesus monkeys and focused on two important problems:

the kinetics of placental transfer and protein incorporation of the amino acid ${ }^{11} \mathrm{C}$-methionine, the uptake and fetal kinetics of morphine and heroin which are sometimes abused by pregnant women.

\section{Curriculum vitae}

Bo LINDBERG, born 1935, MD, PhD. Ass. prof. Since 1980 Senior Medical Officer in perinatal medicine at the University Hospital, Uppsala, Sweden, and head of the Primate Laboratory for Reproductive Research at the University.

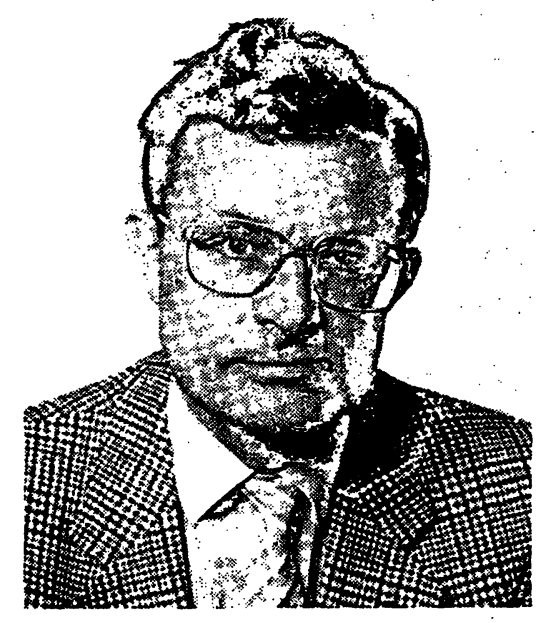

Particular emphasis is given to the methodological aspects of the technique while the original results are presented elsewhere in detail $[2,12]$. Advantages and shortcomings of the PET technique will also be discussed, as well as the application of the method to pharmacokinetic studies of drugs and nutritients in the mother and fetus.

\section{Positron emission tomography}

A positron emission tomographic experiment comprises three steps: production of ra- 
dionucleides, synthesis of ${ }^{11} \mathrm{C}$-labelled radiotracer and investigation by positron emission tomography. Most positron emitters have a rapid physical decay. Thus, the half-life of ${ }^{11} \mathrm{C}$ is only 20.4 minutes.

The decay of ${ }^{11} \mathrm{C}$ produces a positron, the antiparticle of an electron. The positron is thermalized within a mm from the spot of decay in the tissue. The positron mass and an electron mass are annihilated forming two antiparallel photons which are recorded by external detectors. The data collected are utilized for reconstruction of images, representing the radionucleide distribution in transaxial slices of the body by use of standard computerized reconstruction principles. The three steps are described in more detail below.

\subsection{Radionucleide production}

The production of radionucleides was performed at the Tandem Laboratory, University of Uppsala. ${ }^{11} \mathrm{C}$ was produced by bombardment of nitrogen gas with protons $(11 \mathrm{MeV}, 15 \mu \mathrm{A})$. In this method the nascent ${ }^{11} \mathrm{C}$ atoms react with trace amounts of oxygen present in the target gas forming mainly ${ }^{11} \mathrm{CO}_{2}$. The ${ }^{11} \mathrm{CO}_{2}$ molecules are trapped in a molecular sieve and transported to the laboratory for radiochemical synthesis.

\subsection{Organic chemistry}

The positron emitting radionucleide was used in the organic synthesis of the desired radiolabelled compounds. The ${ }^{11} \mathrm{CO}_{2}$ from the accelerator was converted in a series of steps to ${ }^{11} \mathrm{C}$-methyl iodide $[17,18]$. The ${ }^{11} \mathrm{C}$-methyl iodide was used in methylation reactions of homocysteine and the $\mathrm{N}$-demethylated analogues of morphine and heroin, respectively. Samples of the ${ }^{11} \mathrm{C}$-methylated compound were isolated and analyzed with respect to their identity and radiochemical purity. Radiochemical purity was always above 98 per cent and the enantiomeric purity of $\mathrm{L}$ and $\mathrm{D}$ methionine was above 99 per cent $[2,8]$. Before administration to the Rhesus monkey the samples were filtered through $0.22 \mu \mathrm{m}$ membrane filters. The dose of radiolabelled drug varied between $19-93 \mathrm{MBq}$ for ${ }^{11} \mathrm{C}$-morphine and ${ }^{11} \mathrm{C}$-heroin and $110-370$ $\mathrm{MBq}$ for ${ }^{11} \mathrm{C}$-methionine. In some experiments the radiolabelled dose was given together with a dose of the unlabelled analogue.

In the organic chemical preparation of the radiolabelled tracers the time factor is as important as the reaction yield. This is due to the rapid decay of ${ }^{11} \mathrm{C}$ and therefore a minimum of time should elapse from the production of ${ }^{11} \mathrm{CO}_{2}$ to the administration of the radiolabelled compound. The time used including organic synthesis, purification by liquid chromatography and sterilization of the product did never exceed 60 minutes.

\subsection{Animals}

Healthy well-nourished pregnant Rhesus monkeys (Macaca mulatta) from the Primate Laboratory of Reproductive Research in Uppsala were used in the study. The age of the animals ranged between 7 and 15 years, and their weight was between 7.3 and $9.1 \mathrm{~kg}$.

The gestational age at the time of experiment was 120 to 154 days. The monkeys were anesthetized with ketamine I. M., and anesthesia was maintained with repeated doses of 50-100 $\mathrm{mg}$ of ketamine. Two indwelling catheters were inserted in different leg veins, one for administration of the dose, the other for blood sampling. Catheters were also introduced into the urinary bladder and into the amniotic cavity, in the latter case by ultrasonic guidance. During the course of the studies a new technique for sampling of fetal blood was employed. The umbilical vein was punctured by a thin needle under the guidance of ultrasonography [13]. The monkey, was fixed in a specially designed cradle in the positron emission tomograph so that the fetal liver and one placenta were monitored simultaneously. All experiments were carried out after approval of the Committee for Protection of Laboratory Animals at the University of Uppsala. 


\subsection{Positron emission tomography (PET)}

Immediately after administration of the ${ }^{11} \mathrm{C}$ labelled compound imaging of the monkey started. Two antiparallel photons, formed from the annihilation are detected by two opposing detectors fitted in a ring of detectors. A computer controls the detector channels and calculates the distribution of radioactivity in a section of the object defined by the plane of detector rings. The two basic ideas of positron emission are: radionucleide distribution is detected and quantified outside the body; and the co-incidental detection in two opposing detectors in the ring gives an accurate information about the location of radioactivity [3].

A Scanditronix PC 384-3B positron emission tomograph (AB Scanditronix, Uppsala, Sweden) was used. It is equipped with two rings of detectors (96 in each ring) giving three simultaneous images with a slice thickness of $13-14 \mathrm{~mm}$ and a resolution of $8 \mathrm{~mm}$. Data collection and analyses were performed as described by ERIKSSON et al. [6]. A predetermined program was used to record images for 12,40 and $200 \mathrm{sec}$ until the end of the investigation.

\subsection{Evaluation of PET images}

After image reconstruction it is possible to delineate an organ or a part of an organ. The computer quantitates the radioactivity corrected for physical decay per unit of volume in the regions of interest. As the administered radioactivity and the body weight of the monkey are known, a measure denoted "uptake" is calculated. This is defined as $\mathrm{nCi}$ per $\mathrm{cm}^{3}$ of tissue, divided by the dose in $\mathrm{nCi}$ per gram of body weight. An uptake value of 1.0 corresponds to an uptake as if the administered radioactivity was homogeneously distributed in the body of the monkey. The following regions of interests were delineated: fetal liver, placenta, maternal paraspinal muscle and aorta.

\subsection{Pharmacokinetic analysis}

Although PET by itself is non-invasive, additional information may be obtained by com- plimentary techniques. Samples of maternal urine, blood and amniotic fluid were thus collected at regular intervals after dose and counted for total radioactivity in a well counter (NaI [TI]). Radioactivity uptake, as defined above, was measured in blood and amniotic fluid.

Blood samples were centrifuged and the ${ }^{11} \mathrm{C}$ methionine derived radioactivity in the high molecular fraction was measured after gel filtration on Sephadex G25 with saline as mobile phase [16].

In the case of morphine and heroin, the unlabelled drug and the major plasma metabolite, morphine-3-glucuronide (M3G), were analyzed in plasma and amniotic fluid by means of high performance liquid chromatography [19].

\section{Possibilities and shortcomings of PET}

\subsection{Applications of PET}

Positron emission tomography is a non-invasive tracer technique which may be used to measure the kinetics of physiological or biochemical processes in animals or man. Pharmacological studies are often aimed at the study of the interaction in physiological mechanisms by drugs or endogenous compounds. Thus, positron emission tomography provides unique opportunities to study the in vivo kinetics of drugs or the kinetics of incorporation of radiolabelled endogenous compounds in biochemical processes. As only trace amounts of the compound are given, no pharmacological effects are seen, and hence the kinetics can be studied during undisturbed, physiological conditions.

In man, PET has been used in order to measure glucose utilization in the brain in mental disorders, delineate and grade gliomas or pituitary tumours after administration of different ${ }^{11} \mathrm{C}$ labelled amino acids $[4,11,15]$ and it has been used in studies of regional blood flow [1]. Studies have also been performed on the intracerebral distribution of the dopamine antagonist, ${ }^{11} \mathrm{C}$-methyl-spiperone [20], which reflects the dopamine receptor population in the 
human brain. Thus, e. g. it has been shown that the number of receptors decreases with age:

The human studies are often preceeded by experiments in animals to evaluate the organ distribution of the radiotracer and to determine its kinetics in the organ of interest.

Several pharmacokinetic studies have been performed in animals, since the use of PET as an autoradiographic in vivo technique will furnish pharmacologists and pharmacokineticists with data unavailable with other methods. Thus, the uptake and kinetics of narcotic analgesics [8], opioid peptides [9], and dopamine receptor antagonists [20] have been studied in different areas of the brain, as well as bromocriptine in the pituitary [15]. The binding of ${ }^{11} \mathrm{C}$-labelled compounds in different areas of the brain enables one to study the nature of reversible, selective receptor binding and the mechanism of receptor displacement. The irreversible binding of N-methyl-tetra-hydropyridin to melanin containing cells in substantia nigra has thrown light upon the etiology of Parkinsons disease [14]. Distribution of opioids [7] and anesthetics after epidural or intrathecal administration may help to explain the mechanisms behind the late respiratory depression observed in man after spinal application of these drugs. Rapid physiological processes may be described which is of particular value in the studies of transfer of compounds from mother to fetus in pregnancy. Important studies on the extent and rate of transfer of nutrients and drugs $[2,12]$ from the mother to the fetus during pregnancy will be reported below.

This review of some applications gives avidence for the unique possibilities of PET to provide data which cannot be obtained with other techniques. Some shortcomings of the technique will limit its use and create difficulties in the interpretation of the results. These shortcomings may be circumvented by use of additional methods.

\subsection{Shortcomings of PET}

The positron tomograph used has a spatial resolution of $8 \mathrm{~mm}$. This limits the possibilities to study small organs and areas of interest in fetuses. On the other hand, if the pharmacokinetics of the fetus are studied, the whole body kinetics can be integrated over time, as well as the kinetics in a sufficiently large organ such as the liver. The blood borne activity in vividly perfused organs may interfere with the evaluation of the radioactivity in the tissue. Therefore correction for the radioactivity in blood must be made. The blood volume can be estimated after administration of ${ }^{68} \mathrm{Ga}$-EDTA or ${ }^{68} \mathrm{GaCl}_{2}$, which are distributed intravascularly to a high extent. It is thus possible to study the tissue kinetics after correction for the blood borne radioactivity.

In order to separate the ${ }^{11} \mathrm{C}$-derived activity from the metabolites from that of the parent drug, the PET may be complemented by chromatographic methods $[8,16]$.

PET utilizes shortlived radio-isotopes as ${ }^{15} \mathrm{O}$, ${ }^{13} \mathrm{~N}$ and ${ }^{11} \mathrm{C}$ with a half-life of physical decay of minutes. Studies lasting more than 2 hours cannot be done. Autoradiography in small animals can complement the PET images [14]. The uptake of ${ }^{11} \mathrm{C}$-labelled tracer in different organs may also be compared with the radioactivity measured in a well counter from the whole organ obtained after sacrifice of the animal.

The short physical half-life of ${ }^{11} \mathrm{C}$ is an advantage, since the radiation dose will be small. Furthermore, repeated administration of ${ }^{11} \mathrm{C}$ labelled drug in the same animal in the same experimental set up is possible. This means that the animal may serve as its own control when physiology is altered between experiments.

\section{Interpretation of the results}

\subsection{Distribution and lipophilic property}

The time for the drug to reach equilibrium in a well-perfused organ is determined by the blood flow and the distribution ratio of the drug between the tissue and blood. For the uptake in brain, the lipophilic property of the drug is a major determinant besides "binding characteristics in plasma and tissue. The lipophilic 
property of a drug may be expressed as the distribution coefficient between octanol and buffer $\left(\mathrm{pH}=7.4\right.$ at $\left.37^{\circ} \mathrm{C}\right)$. For opioid drugs, meperidine (pethidine) had the most rapid and extensive uptake in the brain followed by heroin, codeine and morphine in order of decreasing lipophilic properties [8]. A higher than expected uptake may indicate some kind of active transport which has been shown for ${ }^{11} \mathrm{C}$ methionine in the brain [4], or it may indicate irreversible binding to structures in the brain as shown for $\mathrm{N}$-phenyl-tetrahydropyridine [14].

The PET images from a ${ }^{11} \mathrm{C}$-heroin experiment are shown in Fig. 1, where the uptake of radioactivity in placenta and fetal liver during the first 27 minutes of the experiment is seen. The uptake of heroin in the fetal liver was more than three times higher than for the more hydrophilic morphine [12]. Maximum uptake was also reached earlier with heroin.

The elimination rate of the ${ }^{11} \mathrm{C}$-derived radioactivity from the brain was in the same range for heroin and morphine. This is probably due to a rapid conversion of ${ }^{11} \mathrm{C}$-heroin to ${ }^{11} \mathrm{C}$ morphine. Therefore, after administration of ${ }^{11} \mathrm{C}$-heroin the late PET-images reflect the disposition of ${ }^{11} \mathrm{C}$-morphine in the fetus.

${ }^{11} \mathrm{C}$-methionine rapidly reached the fetus, probably by a facilitated transport system. It was also shown that the transport system was selective for the L-enantiomer of methionine at the expense of the D-form.
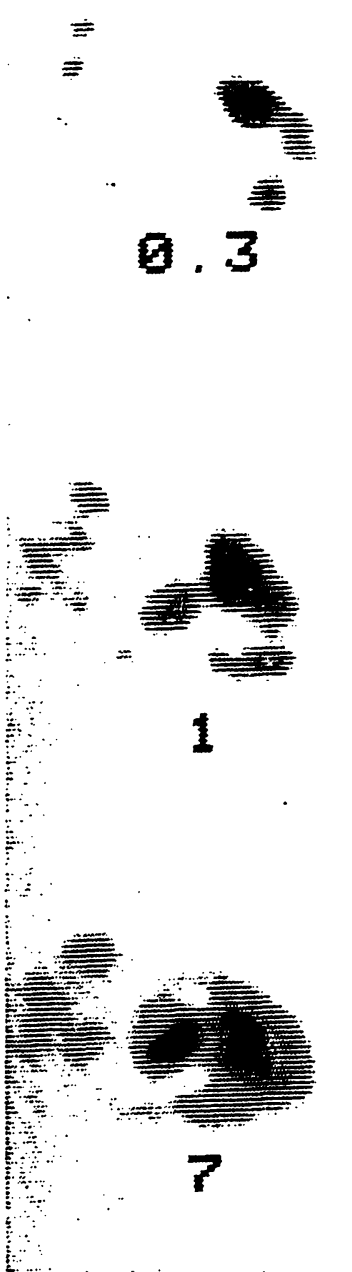

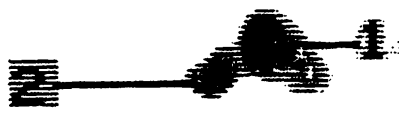

$\pm$

2

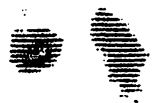

17
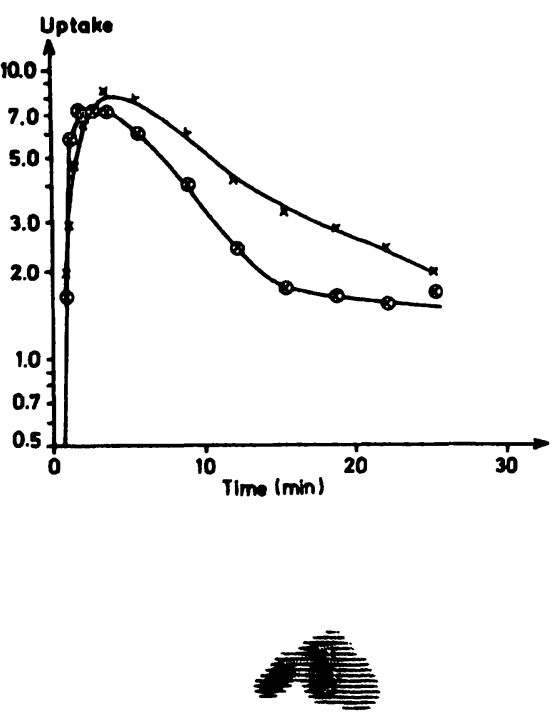

4

Fig.1. PET-images of the distribution of ${ }^{11} \mathrm{C}$ in placenta (1) and fetal liver (2) 0.3 to 27 min after intravenous administration of ${ }^{11} \mathrm{C}$-heroin to a pregnant Rhesus monkey. To the upper right is shown the uptake in the fetal liver (upper curve), and the placental uptake (lower curve), calculated from the regions of interest on the image. 


\subsection{Plasma protein binding}

An extensive plasma protein binding may limit the uptake of the ${ }^{11} \mathrm{C}$-labelled compound in different organs. Endogenous compounds such as amino acids are also readily incorporated in the high molecular fraction in plasma [2]. However, the incorporation was selective and discriminative for the $\mathrm{D}$-form of ${ }^{11} \mathrm{C}$-methionine. Determination of lipophilic properties and plasma protein binding of the ${ }^{11} \mathrm{C}$-labelled tracer is of great importance, not only in interpretation of the PET images, but also in the elucidation of the mechanism of different physiological processes.

\subsection{Pharmacokinetic analysis in plasma, urine and amniotic fluid}

Before equilibrium is attained between blood and tissue, the blood kinetics of a drug is different from that in the tissue. The early phase of drug disposition is prevailing during the course of most PET studies. Therefore, it is of importance to distinguish the kinetics of the tracer in the tissue from that in blood. However, PET studies of drugs with a high lipophilic property and a high extent of non-selective binding in the brain tissue may well give results which are similar to the blood kinetics of the ${ }^{11} \mathrm{C}$-tracer [10]. Blood kinetics cannot be studied by PET because of the radiation from tissues and from drug metabolites. Radiochemical or chemical analyses of ${ }^{11} \mathrm{C}$-labelled drug or unlabelled drug and metabolites in plasma may solve this problem and are performed by means of sensitive and selective chromatographic methods $[8,16]$.

Valuable pharmacokinetic data are obtained from the urine, amniotic fluid and even fetal blood [13]. After administration of ${ }^{11} \mathrm{C}$-morphine together with ${ }^{14} \mathrm{C}$-morphine and unlabelled morphine-3-glucuronide (M3G) to two pregnant Rhesus monkeys, the concentrations of morphine and M3G were measured in plasma, maternal urine, and amniotic fluid [12]. One fetal blood sample was also available.
In the mother, morphine was rapidly converted to M3G. The transfer of morphine to the fetus was slow as was the fetal disposition of both morphine and M3G [12]. At 100 minutes following administration the morphine and $\mathrm{M} 3 \mathrm{G}$ concentrations were higher in the fetus than in the mother. This may reflect the slow transfer of hydrophilic metabolites across the placenta.

\subsection{Pharmacokinetic modelling}

Because of low resolution, the radioactivity measured in the PET-images may derive from adjacent organs, and incorporation of ${ }^{11} \mathrm{C}$-derived radioactivity in a physiological process may be hidden in the unselective uptake of the ${ }^{11} \mathrm{C}$ radiolabelled tracer. Therefore, pharmacokinetic modelling is sometimes mandatory for the interpretation of the results. Modelling can be done in several ways. The easiest way is to administer an analogue, which is not metabolized or cannot be physiologically utilized. The PET-images of the analogue may thus simulate the kinetics of the ${ }^{11} \mathrm{C}$-labelled compound of interest [5]. In the cerebellum, receptor ligands are only bound non-selectively. By subtracting the radioactivity in the cerebellum from that in other areas of the brain, the kinetics of the receptor binding can be described [20].

For more sophisticated analysis a compartment model is required. Such a model for the fetomaternal unit is depicted in Fig. 2. By estimation of the value of the rate constants, the kinetics in maternal and fetal plasma of a drug or an amino acid can be simulated. The results are given in Fig. 3 for morphine which was given to a pregnant Rhesus monkey. A certain resistance to transfer across the placenta was assumed. After insertion of the measured values from the maternal and fetal plasma the different rate constants can be determined.

By extending the compartment analysis to other compartments such as maternal urine and amniotic fluid and inclusion of the data for the main metabolites of morphine, M3G, one may further strengthen the interpretation of the transfer mechanisms in the feto-maternal unit. 


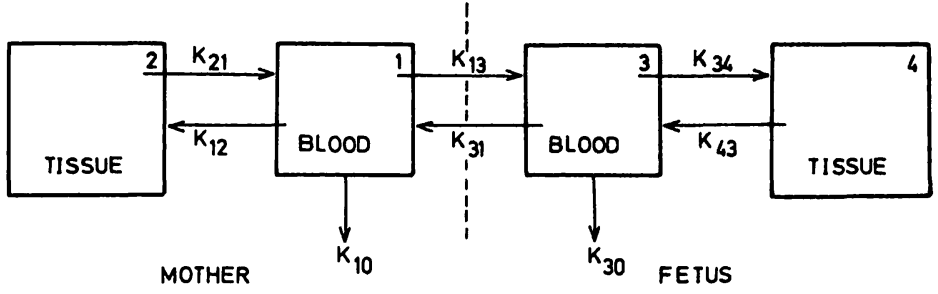

Fig. 2. Pharmacokinetic model for the disposition of morphine in the blood of a Rhesus monkey mother and fetus.

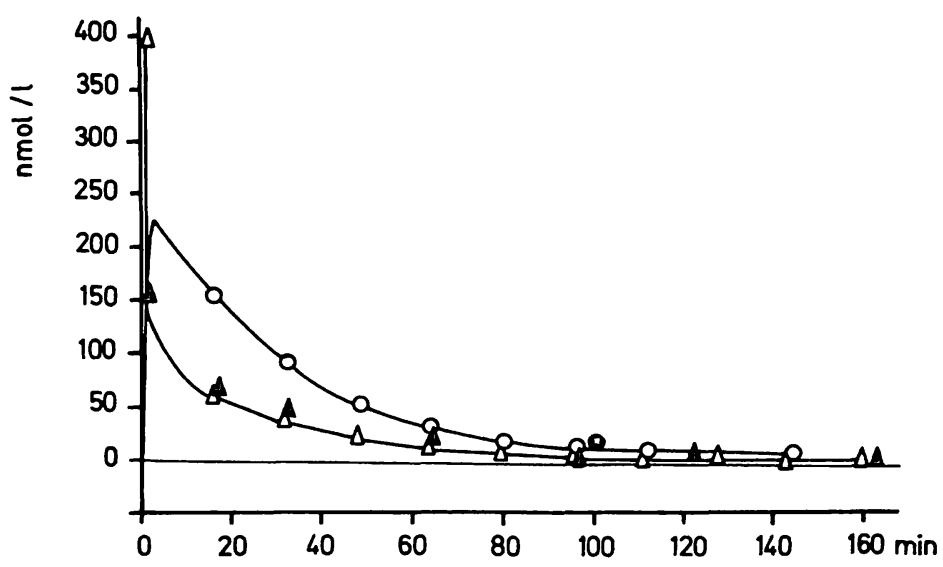

Fig. 3. Simulated concentrations of morphine in the blood of mother (open triangles) and of the fetus (open circles) together with measured values (closed symbols). The pharmacokinetic compartment model depicted in Fig. 2 was used with the following values of the rate constants: $\mathrm{k}_{10}=0.12 ; \mathrm{k}_{12}=0.70 ; \mathrm{k}_{21}=0.30 ; \mathrm{k}_{34}=0.70$; $\mathrm{k}_{43}=0.30 ; \mathrm{k}_{13}=0.003$ and $\mathrm{k}_{31}=0.0015 \mathrm{~min}^{-1}$. Simulation was made with the pharmacokinetic computer program DARE-P at UDAC at the University of Uppsala.

\section{Summary}

Positron emission tomography (PET) is a new tracer technique by which short-lived radionucleides, such as ${ }^{11} \mathrm{C}$ are used for labelling drugs, amino acids and other compounds. The concentration in the various organs is determined non-invasively after I. V. injection. Positrons, emitted by ${ }^{11} \mathrm{C}$ attract an electron, and the two masses are annihilated by emitting photons. These can be registered by external detectors. Measurement of the radioactivity per volume of tissue as a function of time is accomplished by computerized processing of the data. The PET technique may be used for studies of the kinetics of the injected compound in different organs of the body. However, PET registers only the total radioactivity meaning that the measured ${ }^{11} \mathrm{C}$-radioactivity represents the sum of the parent compound and the radiolabelled metabolites. Chemical and radiochemical analyses in various body fluids may then help to interpret the PET images.
The model can be employed for all kinds of compounds and by inclusion of PET data a full description of the kinetics is obtained.

\section{Conclusions}

The PET technique is based on several sciences e. g. physics, radiobiology, organic chemical synthesis, pharmacology, pharmacokinetics, radiology and several clinical disciplines. The number of people involved in a PET-experiment is in the order of $4-8$. The high costs of the method may hamper its further development in experimental pharmacology.

PET has many applications but one of its major impacts has been in studies on the kinetics and transfer mechanisms in the feto-maternal unit. Because of its non-invasive character, the PET methodology gives information which are unavailable by other techniques. Since studies are performed in the Rhesus monkey the results may be extrapolated to man. The placental transfer mechanisms are studied by pharmacokinetic modelling, which support the interpretation of the results. The presented method is of interest in studies of develop mental pharmacology in the feto-placental unit and is applicable to several types of compounds, including nutrients and drugs ingested or abused by the mother.

The major use of PET has been in studies of metabolism and receptor binding in the brain. The present paper is a review of the PET technique as used in experimental perinatal medicine.

We have employed PET in kinetic studies of methionine in the fetomaternal unit of Rhesus monkeys. After I. V. injection of ${ }^{11} \mathrm{C}$-L- or D-methionine, the distribution of radioactivity in maternal muscles, placenta and fetal liver were registered. There was a rapid transport of ${ }^{11} \mathrm{C}$ activity to the fetal compartments after administration of the two enantiomers. By analyses of the radioactivity in maternal plasma after gel separation, it was found that only the L-form was used in the protein synthesis. PET is thus suitable for studies of stereospecific kinetics and metabolism of amino acids in the feto-maternal unit.

In another project, the kinetics of the opiates ${ }^{11} \mathrm{C}$-morphine and ${ }^{11} \mathrm{C}$-heroin were studied in pregnant Rhesus 
monkeys. The opiates were rapidly metabolized why the PET images had to be complemented by analyses of samples from maternal blood, urine, and amniotic fluid. Fetal blood was also obtained through puncture of the umbilical vein.

Both ${ }^{11} \mathrm{C}$-morphine and ${ }^{11} \mathrm{C}$-heroin were rapidly transported to the fetus. The heroin derived ${ }^{11} \mathrm{C}$-activity in the fetal liver was almost three times higher than that of ${ }^{11} \mathrm{C}$-morphine, which may reflect the difference in lipophilic property between these drugs. The con- centration of morphine in fetal blood was twice that in maternal blood after $100 \mathrm{~min}$.

Data from PET studies of morphine in the feto-maternal unit were used in the simulation of pharmacokinetic compartment models. Such simulation may aid in the interpretation of results from PET studies, and eliminate the need for additional analyses of body fluids. Thus, the non-invasive character of PET implies a great potential for studies in experimental perinatal medicine.

Keywords: Carbon-11, methionine, opiates, placental transfer, positron emission tomography, pregnancy, Rhesus monkeys.

\section{Zusammenfassung}

\section{Positron-Emissionstomographie in der experimentellen Perinatologie}

Die Positron-Emissionstomographie (PET) ist eine neue Technik, die auf der Markierung von Medikamenten, Aminosäuren und anderen Verbindungen mit kurzlebigen Nukliden wie z. B. ${ }^{11} \mathrm{C}$ basiert. Nach i. v.-Injektionen kann die Konzentrationsbestimmung in den verschiedenen Organen nicht-invasiv erfolgen. Die durch das ${ }^{11} \mathrm{C}$ emittierten Positronen ziehen ein Elektron an und unter Aussendung von Photonen löschen sich die beiden Massen aus. Dieser Vorgang kann durch externe Detektoren registriert werden. Die Messung der Radioaktivität, die pro Volumeneinheit in einem Gewebe in Abhängigkeit von der Zeit auftritt, erfolgt über eine computergesteuerte Datenerfassung. Über die PET läßt sich die Kinetik der injizierten Verbindungen in den verschiedenen Körperorganen verfolgen. Jedoch erfaßt die PET die Gesamtaktivität, d. h. sowohl die Aktivität der Ausgangsverbindung wie auch die der radioaktiven Metabolite. Chemische und radiochemische Analysen der verschiedenen Körperflüssigkeiten können dann die Interpretation der PET-Bilder erleichtern.

Bisher wurde die PET bei Untersuchungen von metabolischen Prozessen und Rezeptoren im Gehirn eingesetzt. Die vorliegende Arbeit berichtet über den Einsatz der PET in der experimentellen Perinatalmedizin.

Wir haben mit der PET die Kinetik des Methionins in der fetomaternalen Einheit bei Rhesusaffen untersucht. Nach i. v.-Injektion von ${ }^{11} \mathrm{C}$-markiertem L- oder DMethionin wurde die Verteilung der Radioaktivität im mütterlichen Muskelgewebe, in der Plazenta und in der fetalen Leber registriert. Dabei wurde ein rascher Trans-

Schlüsselwörter: ${ }^{11} \mathrm{C}$, Methionin, Opiate, plazentarer Schwangerschaft. port der beiden Verbindungen zu den fetalen Kompartimenten beobachtet. Die Untersuchung des maternalen Plasmas mit Hilfe der Gelelektrophorese zeigte, daß ausschließlich die L-Form bei der Proteinbiosynthese eingebaut wird. Die PET ist somit auch zur Untersuchung der stereospezifischen Kinetik und des Metabolismus von Aminosäuren in der fetomaternalen Einheit geeignet.

In einer anderen Studie wurde die Kinetik der Opiate ${ }^{11} \mathrm{C}$-Morphin und ${ }^{11} \mathrm{C}$-Heroin bei schwangeren Rhesusaffen untersucht. Die Opiate wurden rasch metabolisiert; die PET-Bilder wurden durch Analysen von mütterlichen Blut- und Urinproben sowie Fruchtwasserproben ergänzt. Zur Gewinnung von fetalem Blut wurde die Nabelvene punktiert.

Sowohl ${ }^{11} \mathrm{C}$-Morphin wie auch ${ }^{11} \mathrm{C}$-Heroin wurden rasch zum Feten transportiert. In der fetalen Leber war die vom Heroin abstammende Radioaktivität dreimal höher als die vom ${ }^{11} \mathrm{C}$-Morphin, was die unterschiedliche Fettlöslichkeit dieser beiden Verbindungen widerspiegelt. Nach 100 Minuten war die Konzentration des Morphins im fetalen Blut doppelt so hoch wie im mütterlichen Serum.

Auf der Basis der PET-Studien mit Morphin in der fetomaternalen Einheit wurde ein pharmakokinetisches Modell für Untersuchungen in verschiedenen Kompartimenten simuliert. Eine solche Simulation erleichtert die Interpretation von PET-Ergebnissen; auf eine zusätzliche Analyse von Körperflüssigkeiten kann dann verzichtet werden. Aus dem nicht-invasiven Charakter der PET ergibt sich ein großes Potential für experimentelle IStudien in der Perinatalmedizin.

\section{Résumé}

Tomographie à émission de positron en périnatalogie expérimentale

La tomographie à émission de positron (T. E. P.) est une nouvelle technique de marquage au cours de laquelle on utilise des radionucléides à vie courte, tels que le $11 \mathrm{C}$, pour marquer des médicaments, des. acides aminés et autres composés. On détermine de façon non invasive la concentration dans les divers organes après injection 
I. V. Les positrons émis par le $11 \mathrm{C}$ attirent un électron et les deux masses sont annihilćes en émettant des photons. Ces photons peuvent être enregistrés par des détecteurs externes. La mesure de la radioactivité par volume de tissu en fonction du temps est réalisée par traitement informatique des données. La technique T.E.P. peut ctre utilisée pour ćtudier la cinétique des composés injectés dans les différents organes du corps. Toutefois, la T. E.P. n'enregistre que la radioactivité totale ce qui signifie que la radioactivité $11 \mathrm{C}$ mesuréc représente la somme des composés injectés et des métabolites marqués. Les analyses chimiques et radiochimiques des divers fluides de l'organisme peuvent alors aider à interpréter les images T. E. P.

L'utilisation principale de la T. E.P. a été l'étude du métabolisme et de la fixation sur les recepteurs au niveau cérébral. Cet article est une revue de techniques de la T. E. P. dans son utilisation en médecine périnatale expérimentale.

Nous avons employé la T. E. P. dans les ćtudes cinétiques de la méthionine dans l'unité foto-maternelle de singes Rhésus. On a enregistré la distribution de la radioactivité dans les muscles maternels, le placenta et le foie fœtal après injection I. V. de $11 \mathrm{C}$. L. ou D. méthioninc. Il y a un transport rapide de l'activité $11 \mathrm{C}$ vers les compartiments fotaux après administration des deux enantiomères. En analysant la radioactivité sur gel, on a trouvé que seule la forme $L$ est utilisée pour la synthèse protéi- que. Ainsi, la T. E. P. est appropriće pour les études des cinétiques stcréo-spécifiques et du métabolisme des acides aminés dans l'unité foto-maternelle.

Dans un autre projet, les cinétiques des opiacés morphine $11 \mathrm{C}$ et héroïne $11 \mathrm{C}$ ont étć étudićes chez des guenons rhésus gravides. Les opiacés sont rapidement métabolisés c'est pourquoi les images de T. E. P. doivent ĉtre complétées par l'analyse d'échantillons de sang maternel, d'urine et de liquide amniotique, on a également obtenu du sang fotal par ponction de la veine ombilicale. La morphinc $11 \mathrm{C}$ et l'héroïne $11 \mathrm{C}$ sont rapidement transportés vers le foetus. L'activité $11 \mathrm{C}$ dans le foie fœetal, en provenance de l'héroïne est presque trois fois plus élevée que celle dérivant de la $11 \mathrm{C}$ morphine, ce qui peut refléter la différence de lipophilic entre ces substances. Les concentrations de morphine dans le sang fotal sont le double de celles du sang maternel au bout de 100 minutes.

Les données tirées des études avec T. E. P. de la morphine dans l'unité fœeto-maternelle ont été utilisées pour la simulation de modèles de compartiments pharmacocinétiques. De telles simulations peuvent aider l'interprétation des résultats provenant des études de T. E. P. et éliminer la necessité d'analyses complémentaires des liquide de l'organisme. Ainsi, le caractère non invasif de la T. E. P. souligne son vaste potentiel pour les études concernant la médecine périnatalc expérimentale.

Mots-clés: Carbone 11, grossesse, méthionine, opiacés, singes Rhésus, tomographie à émission de positrons, tranfert placentaire.

Acknowledgements: Supported by grants from the Swedish Medical Research Council (14X-04496, 19X-0719401A) and The Expressen Prenatal Research Foundation.

\section{Bibliography}

[1] Beaney, P. D., A. A. Lammertsmaa, T. Jones, C. G. MCKenzIE, K. E. Holan: Positron emission tomography for in-vivo measurement of regional blood flow, oxygen utilization and blood volume in patients with breast carcinoma. Lancet 1 (1984) 131

[2] Berglund, L., C. Halldin, A. Lilja 2 B. S. LindBERG, H. LUNDQVIST, B. LANGSTRÖM, $P$. Malmborg, K. NÅgRen, C.-G. StÅlnaCke: ${ }^{11} \mathrm{C}$ methionine kinetics in pregnant Rhesus monkeys studied by positron emission tomography: a new approach to feto-maternal metabolism. Acta Obstet. Gynecol. Scand. 63 (1984) 641

[3] Bergström, M., L. Eriksson, C. BoHM: Correction for scattered radiation in a ring detector positron camera by internal transformation of the projections. J. Comput. Assist. Tomogr. 7 (1983) 42
[4] Bustany, P., T. Sargent, J. M. Saudubray, J. F. HENRY, D. COMAR: Regional human brain uptake and protein incorporation of ${ }^{11} \mathrm{C}$ - $\mathrm{L}$-methionine studied in vito with PET. J. Cerebr. Blood Flow Metab. 1 (1981) S 17

[5] ECKERNÄs, S. A., S. M. Aquilonius, K. Bergström, P. Hartvig, A. LiLja, B. S. Lindbirg, H. LUNDQVIST, B. LANGSTRÖM, P. MALMBORG, U. MOSTRÖM, K. NÅGREN: The use of positron emission tomography for the evaluation of choline metabolism in the brain of the Rhesus monkey. In: Dynamics of Cholinergic Function. Raven Press. In press

[6] Eriksson, L., C. Bohim, M. Bergström, K. EricSON, T. Greitz, G. BlomQVist, J. LitToN, P. HANSEN, S. HOLTE, H. StJeRnberg: Design characteristics of a multiring positron camcra system 
for emission tomography of the brain. In: Heiss, W.-D., M. E. Phelps: Positron emission tomography of the brain. p. 40. Springer Verlag, Berlin, Heidelberg and New York 1983

[7] Gustafsson, L., P. Hartvig, K. Bergström, H. LUNDQVIST, B. S. LINDBERG, B. LÅNGSTRÖM, A. RANE, A. Rimland, H. SvÄrD, A. TAMSEN: Kinetics of ${ }^{11} \mathrm{C}$-labelled morphine and meperidine after epidural and intrathecal administration to Rhesus monkey. Submitted to Drug Metab. Dispos.

[8] Hartvig, P., K. Bergström, B. S. Lindberg, P. O. LUNDBERG, H. LUNDQVIST, B. LÅNGSTRÖM, $H$. SVÄRD, A. RANE: Kinetics of ${ }^{11} \mathrm{C}$-labelled opiates in the brain of Rhesus monkeys. J. Pharmacol. Exp. Ther. 230 (1984) 250

[9] Hartvig P., P. O. Lundberg, H. Lundevist, B. S. LindBerg, L. TERENIUS, K. NÅgReN, B. LÅNGSTRÖM: Kinetics of four ${ }^{11} \mathrm{C}$-labelled opioid peptides in the brain and blood of Rhesus monkeys. Manuscript

[10] Hartvig P., A. Tamsen, A. Lilja, K. Bergström, P. O. LUNDBERG, S. Å. ECKERNÄS, B. S. LINDBERG, H. SVÄRD, B. LÅNGSTRÖM, H. LUNDQVIST, A. RANE: Distribution of morphine to the brain of Rhesus monkeys. In: NÄNTö, V., E. M. SUOLINNA (eds.): Proceedings 3rd Symposium on the medical application of cyclotrons. Ann. Univ. Turkuensis Ser. D. Medica- Odontologica 17 (1984) 269

[11] Lilja, A., K. Bergström, P. Hartvig, B. SpännaRE, C. Halldin, H. Lundevist, B. LÅngSTRÖM: Dynamic studies of supratentorial gliomas with L[methyl- ${ }^{11} \mathrm{C}$ ]-methionine and positron emission tomography (PET). Am. J. Neuroradiol. In press 1985

[12] Lindberg, B. S., P. Hartvig, A. Lilja, H. LundQVIST, B. LÅNGSTRÖM, A. RANE: Positron emission tomography: A new approach to feto-maternal pharmacokinetics. National Institute on Drug Abuse; NIDA Res. Monograph. In press

[13] LindGren, P.-G., B. S. LindBerg: Fetal blood sampling by ultrasound-guided puncture of the umbilical vein in Rhesus monkeys. J. Med. Primatol. 14 (1985) 159
[14] Lindquist, N. G., P. Hartvig, S. M. Aquilonius, K. BERGSTRÖM, U. BONDESSON, R. D'ARGY, S. A. ECKERNÄs, P. GULlberG, B. S. LARSSON, A. LYDÉN, B. S. LINDBERG, H. LUNDQVIST, B. LÅNGSTRÖM, P. MALMBORG, K. NÅGREN: Distribution of 1-methyl4-phenyl-1,2,5,6-tetrahydropyridine in experimental animals studied by positron emission tomography and whole body autoradiography. Submitted to Life Sci.

[15] Lundberg, P. O., C. Muhr, P. Hartvig, K. BeRGSTRÖM, H. LUUNDQVIST, B. LÅNGSTRÖM: The use of positron emission tomography (PET) in psychoendocrine research. Methods and possibilities. Submitted to Psychoneuroendocrinology

[16] LundQVist, H., C.-G. STÅlNACKE, B. LÅNGSTRÖM, B. JoNES: Labelled metabolites of ${ }^{11} \mathrm{CH}_{3}$-L-methionine. In: WIDÉN, L., T. GReITZ, D. INGVAR (eds.): Human brain metabolism studied with positron emission tomography. pp. $233-240$. Raven Press, New York 1985

[17] LÅngström, B., G. Antoni, C. Halldin, H. SVÄRD, G. BERGSON: Synthesis of some ${ }^{11} \mathrm{C}$-labelled alkaloids. Chem. Scripta 20 (1982) 46

[18] LÅNGSTRÖM, B., H. LUNDQVIST: The preparation of ${ }^{11} \mathrm{C}$-methyl iodide and its use in the synthesis of ${ }^{11} \mathrm{C}$-methyl-L-methionine. Int. J. Appl. Radiat. Isot. 27 (1976) 357

[19] Svensson, J.-O., A. Rane, J. Säwe, F. SJöQvist: Determination of morphine, morphine-3-glucuronide and (tentatively) morphine-6-glucoronide in plasma and urine using ion-pair high performance liquid chromatography. J. Chromatogr. 230 (1982) 427

[20] Wagner, H., D. Burns, R. Dannals, D. Wong, B. LÅngström, T. Duelfer, J. Frost, H. Ravert, J. M. LINKS, S. B. Rodenblom, S. LUKAS, A. KRAMER, M. KUHAR: Imaging dopamine receptors in the human brain. Science 221 (1983) 1264

Received October 5, 1984. Accepted November 6, 1984.

Bo Lindberg, M. D.

Department of Obstetrics and Gynecology University Hospital

75185 Uppsala, Sweden 